Egypt. Acad. J. biolog. Sci., 2 (1):63-76 (2010)

Email: egyptianacademic@yahoo.com

Received: $26 / \mathbf{4} / \mathbf{2 0 1 0}$
F. Toxicology \& pest control

ISSN: 2090 - 0791

www.eajbs.eg.net

\title{
Toxicological Effects of Some Heavy Metal Ions on Culex pipiens L. (Diptera: Culicidae)
}

\author{
Tarek M. Y. El-Sheikh; Mohamad A. Fouda; Mostafa I. Hassan; Abd-Elhamed \\ A. Abd-EIghaphar and Ahmed I. Hasaballah \\ Department of Zoology, Faculty of Science (boys), Al-Azhar University, Nasr City, \\ Cairo, Egypt, \\ E-mail: Tarek_elshekh2000@yahoo.com
}

\begin{abstract}
Different concentrations of selected heavy metals in the form of cadmium chloride $\left(\mathrm{CdCl}_{2}\right)$, copper sulphate $\left(\mathrm{CuSO}_{4}\right)$, lead nitrate $\left(\mathrm{Pb}\left(\mathrm{NO}_{3}\right)_{2}\right)$ and mercuric nitrate $\left(\mathrm{Hg}\left(\mathrm{NO}_{3}\right)_{2}\right)$ were tested against immature and mature stage of $C$. pipiens to assess the toxicity, $\mathrm{LC}_{50}$, total carbohydrate and lipid content. The survival potential of $2^{\text {nd }}$ instar larvae was highly affected by the contamination with the tested heavy metals. On the basis of $\mathrm{LC}_{50}, \mathrm{Cd}$ was the most toxic metal against the larval stage followed by $\mathrm{Hg}, \mathrm{Cu}$ and $\mathrm{Pb}$. The late toxicity of heavy metals tested on the adult females resulted from larvae treated with the $\mathrm{LC}_{50}$ of each heavy metal decreased significantly the number of eggs laid by female. The fecundity recorded $81.7 \pm 5.03$, $90.3 \pm 2.52,92.7 \pm 3.5$ and $78.6 \pm 1.52 \mathrm{eggs} / q$ for females resulted from larvae treated with the $\mathrm{LC}_{50}$ of $\mathrm{CdCl}_{2}, \mathrm{CuSO}_{4}, \mathrm{~Pb}\left(\mathrm{NO}_{3}\right)_{2}$ and $\mathrm{Hg}\left(\mathrm{NO}_{3}\right)_{2}$; respectively, compared to $186 \pm 4$ eggs/ 9 for control females. The hatchability percent of eggs laid with the $\mathrm{LC}_{50}$ of $\mathrm{CdCl}_{2}, \mathrm{CuSO}_{4}, \mathrm{~Pb}\left(\mathrm{NO}_{3}\right)_{2}$ and $\mathrm{Hg}\left(\mathrm{NO}_{3}\right)_{2}$ was significantly decreased to 37, 73, 80 and $39 \%$; respectively, compared to $97 \%$ for eggs laid by untreated females. A significant decrease in total carbohydrate content in the whole body of males and females, C. pipiens resulted from larvae treated with the $\mathrm{LC}_{50}$ of $\mathrm{CdCl}_{2}$ or the $\mathrm{LC}_{50}$ of $\mathrm{Hg}\left(\mathrm{NO}_{3}\right)_{2}$ was observed. Also, the present study showed a significant decrease in total lipid content of females by the $\mathrm{LC}_{50} \mathrm{CuSO}_{4}$ and the $\mathrm{LC}_{50}$ of $\mathrm{Hg}\left(\mathrm{NO}_{3}\right)_{2}$, while in males a significant increased was caused by the $\mathrm{LC}_{50} \mathrm{CuSO}_{4}$ and the $\mathrm{LC}_{50}$ of $\mathrm{Pb}\left(\mathrm{NO}_{3}\right)_{2}$. It is clear from the results obtained in this study that the presence of such elements in the environmental system of the mosquito C. pipiens water as possible to contribute to the reduction of mosquito breeding.
\end{abstract}

Key words: Heavy metals, Toxicity, Fecundity, Hatchability, C. pipiens.

\section{INTRODUCTION}

Heavy metals such as cadmium, chromium, copper, iron, lead, manganese and zinc are environmentally dangerous substances, and this necessitates their surveillance in aquatic environments. Low concentrations of heavy metals occur in natural aquatic ecosystems, but recent expansions in human population growth, industry, and peri-urban agricultural activities in African cities have led to an increase in heavy metal occurrence in excess of natural loads (Biney et al., 1994).
Heavy metal pollution can have a devastating effect on the ecological balance of aquatic environments, limiting the diversity of aquatic organisms and plants. For instance, there are indications that the level of pollution in water bodies directly influences the diversity and abundance of larval stage mosquito species (Chinery, 1984; Coluzzi, 1993 and Coene, 1993).

Anopheles mosquito populations are typically lower in urban environments as compared to rural environments because of high levels of 
human pollution and perturbation (Trape and Zoulani, 1987). The level of heavy metal contamination may play a limiting role on Anopheles mosquito populations in urban environments (Mireji et al., 2008).

The biological impact of heavy metals on aquatic insects has been extensively studied in nature and in the laboratory (e. g. Cain et al., 1992; Clements and kiffiney, 1994; Dallinger, 1994 and Rayms-Keller et al., 1998). Aquatic insects accumulate heavy metals and have long been exploited as indicator species of environmental pollution and for bioassays of pollutants (Hare, 1992). In addition to mortality, exposure of aquatic insects to heavy metals can result in changes in fecundity and fertility. However, only scattered information on effects of heavy metal stress on metabolism, structure and function of the reproductive organs in mosquitoes is available.

Mosquitoes serve as vectors of many vertebrate blood pathogens; Culex pipiens is a very common mosquito species in Egypt and is the predominant vector of Wuchereria bancrofti that causes filariasis or elephantiasis in humans (Khalil et al., 1930 and Gad et al., 1996), Rift Valley fever virus (Meagan et al., 1980; Darwish and Hoogstraal, 1981) and West Nile virus (Pelah et al., 2002).

The present investigation was carried out to study the larvicidal effects of exposure to selected heavy metal ions namely; cadmium $(\mathrm{Cd})$, copper $(\mathrm{Cu})$, lead $(\mathrm{Pb})$ and mercury $(\mathrm{Hg})$ on $C$. pipiens. Moreover, to study certain biological effects such as total carbohydrate, lipid, female fecundity and hatchability.

\section{MATERIALS AND METHODS 1- Origin and laboratory maintenance of the mosquito colony:}

Mosquitoes used in this study were Culex pipiens L., they were collected from Abu Rawash, Giza governorate, then were reared for several generations, in the insectary of Medical Entomology at the Department of Zoology, Faculty of Science, Al-Azhar University, under controlled conditions at temperature of $27 \pm 2{ }^{\circ} \mathrm{C}$, relative humidity $70 \pm 10 \%$ and $12-12$ light-dark regime. Adult mosquitoes were kept in $(30 \times 30 \times 30 \mathrm{~cm})$ wooden cages and daily provided with sponge pieces soaked in $10 \%$ sucrose solution for a period of 3 4 days after emergence. After this period the females were allowed to take a blood meal from a pigeon host, which is necessary for laying eggs (anautogeny). Plastic cup oviposition $(15 \times 15 \mathrm{~cm})$ containing dechlorinated tap water was placed in the cage.

The resulting egg rafts picked up from the plastic dish and transferred into plastic pans $(25 \times 30 \times 15 \mathrm{~cm})$ containing 3 liters of tap water left for $24 \mathrm{~h}$. The hatching larvae were provided daily with fish food as a diet. This diet was found to be the most preferable food for the larval development and a well female fecundity, (Kasap and Demirhan, 1992).

\section{2- Heavy metals tested:}

The salts of heavy metals used in this work were; cadmium chloride $\left(\mathrm{CdCl}_{2}\right)$, copper sulphate $\left(\mathrm{CuSO}_{4}\right)$, lead nitrate $\left(\mathrm{Pb}\left(\mathrm{NO}_{3}\right)_{2}\right)$ and mercuric nitrate $\left(\mathrm{Hg}\left(\mathrm{NO}_{3}\right)_{2}\right)$, each of these salts was dissolved in distilled water (dist.) to make a stock solution of $1000 \mathrm{ppm}$. The stock solution was then diluted to make a series of different concentrations. The concentrations were: A) $\mathrm{CdCl}_{2}: 0.05,0.1$, 0.15, 0.2 and 0.3 ppm. B) $\mathrm{CuSO}_{4}: 1,2,4$, 8 and 10 ppm. C) $\mathrm{Pb}\left(\mathrm{NO}_{3}\right)_{2}: 8,16,32$, 50 and 75 ppm. D) $\mathrm{Hg}\left(\mathrm{NO}_{3}\right)_{2}: 0.1,0.2$, $0.5,0.7$ and $1 \mathrm{ppm}$.

\section{3- Experimental bioassay:}

In order to study the toxicity of these heavy metals, different range of concentrations of each heavy metal salt was used. The $2^{\text {nd }}$ instar larvae were collected from the established colony and placed in plastic cup its diameter was 12 
$\mathrm{cm}$ and its hight was $7 \mathrm{~cm}$ containing 250 $\mathrm{ml}$ of the metal salt solution as recommended by (WHO). Control larvae were placed in cups contained $250 \mathrm{ml}$ dechlorinatedtap water $\left(25\right.$ of $2^{\text {nd }}$ instar larvae/cup). At least three replicates were used in each experiment. All plastic cups were incubated under controlled conditions at temperature of $27 \pm 2{ }^{\circ} \mathrm{C}$, relative humidity $70 \pm 10 \%$ and $12-12$ light-dark regime. The following biological aspects were used to evaluate the effect of the four heavy metals on $C$. pipiens.

\section{3-1- Larvicidal activity:}

Mortality was recorded daily and dead larvae removed until adult emergence. Mortality of the larvae was indicated by a failure to respond to mechanical stimulation (Williams et al. 1986). Larval mortality percent was estimated by using the following equation: Larval mortality $\%=\mathrm{A}-\mathrm{B} /$ $\mathrm{A} \times 100$ (Briggs, 1960): Where: $\mathrm{A}=$ number of tested larvae. $\mathrm{B}=$ number of tested pupae.

\section{3-2- Female fecundity:}

The adult females that succeeded to emerge from the $2^{\text {nd }}$ instar larvae treated with each concentration were collected and transferred with normal adult males obtained from the colony to the wooden cages $(20 \times 20 \times 20 \mathrm{~cm})$ by using an electric aspirator recommended by (WHO), and fed with $10 \%$ sugar solution for three days, then, the adult males and females leaved one day without sugar solution. At five day, the starved females were allowed to take a blood meal from a pigeon and allowed to lay egg rafts on clean water. The number of eggs/raft was counted by using binocular microscope and the mean value was taken.

\section{3-3- Egg hatchability:}

The eggs of females resulted from the $2^{\text {nd }}$ instar larvae treated with $\mathrm{CdCl}_{2}$, $\mathrm{CuSO}_{4}, \mathrm{~Pb}\left(\mathrm{NO}_{3}\right)_{2}$ and $\mathrm{Hg}\left(\mathrm{NO}_{3}\right)_{2}$ were counted by using a binocular microscope. The eggs were sorted into two categories: hatched and non-hatched eggs according to the method used by Hassan et al. (1996).

The Egg-hatchability was calculated by using the following equation: Egg-hatchability $\%=\mathrm{A} / \mathrm{B} \times$ 100, Where: $A=$ total No. of hatched eggs. $\mathrm{B}=$ total No. of eggs laid.

\section{4- Biochemical studies:}

The resulting adult males and females from treated $C$. pipiens larvae with the $\mathrm{LC}_{50}$ of each of $\mathrm{CdCl}_{2}, \mathrm{CuSO}_{4}$, $\mathrm{Pb}\left(\mathrm{NO}_{3}\right)_{2}$ and $\mathrm{Hg}\left(\mathrm{NO}_{3}\right)_{2}$ were collected daily, weighed and kept under freezing condition at $4^{\circ} \mathrm{C}$ until the biochemical determinations. For the determination of the total protein, lipid and carbohydrate, adults were homogenized in saline solution (40 adults/ $1 \mathrm{ml}$ saline solution) using a fine electric homogenizer, tissue grinder for 2 minutes (min.). Homogenates were centrifuged at 4000 r.p.m. (rotate per min.) for $15 \mathrm{~min}$. at $2^{\circ} \mathrm{C}$ in a refrigerated centrifuge. The supernatant was used directly or stored at $4^{\circ} \mathrm{C}$ until biochemical determination.

4-1-Determination of the total carbohydrate content:

The total carbohydrate content of the whole adult body was determined.

\section{4-2- Determination of the total lipid content:}

The total lipid content was determined by colourimetric method of (Frings et al., 1972). A sample of whole body extract was heated with conc. sulphuric acid and the mixture was then reacted with phosphoric acid-vanilline reagent to give red to purple colour. The intensity of colour was measured by photoelectric colourimeter (Carlziss).

\section{Statistical analysis:}

The statistical analysis of the obtained data was done according to Armitage (1974) and Lentner et al. (1982). The analysis was revised and graphics were drown by Excel for windows program version 2 Microsoft office 2010. The obtained data were assessed by calculation of the mean (M), 
standard deviation (SD) and student ttest. $\mathrm{LC}_{50}$ was calculated using multiple linear regressions (Finney, 1971).

\section{RESULTS}

\section{1- Biological activity of heavy metals} against Culex pipiens:

1-1- Toxicity:

A- Cadmium:

The mortality percentages of $C$. pipiens larvae as influenced by different concentrations of cadmium chloride $\left(\mathrm{CdCl}_{2}\right)$ are given in table (1). The obtained data indicated that there was a positive correlation between the concentration of the $\mathrm{CdCl}_{2}$ and the mortality percent i.e. the increase of $\mathrm{CdCl}_{2}$ concentration led to the increase of larval mortality percent.

The larval mortality percent increased gradually from $30.6 \%$ at the concentration of $0.05 \mathrm{ppm}$ to $92.0 \%$ at the concentration of $0.3 \mathrm{ppm}$. The larval mortality percent among the control group was $10.6 \%$. The calculated $\mathrm{LC}_{50}$ from the different mortality percentages recorded $0.11 \mathrm{ppm}$.

Table 1: Effect of different concentrations of $\mathrm{CdCl}_{2}$ on larval mortality of $C$. pipiens.

\begin{tabular}{|c|c|c|c|c|}
\hline $\begin{array}{l}\text { Conc. } \\
\text { (ppm) }\end{array}$ & No. of larvae tested & No. of larvae died & Mortality percent & $\begin{array}{c}\mathbf{L C}_{50} \\
\text { (ppm) }\end{array}$ \\
\hline 0.05 & 75 & 23 & 30.6 & \multirow{6}{*}{0.11} \\
\hline 0.1 & 75 & 39 & 52.00 & \\
\hline 0.15 & 75 & 47 & 62.6 & \\
\hline 0.2 & 75 & 56 & 74.7 & \\
\hline 0.3 & 75 & 69 & 92.00 & \\
\hline Control & 75 & 8 & 10.6 & \\
\hline
\end{tabular}

\section{B- Copper:}

The data given in table (2) Showed the effect of different concentrations of copper sulphate $\left(\mathrm{CuSO}_{4}\right)$ on the larval mortality percentages. There was a positive correlation between the concentration of $\mathrm{CuSO}_{4}$ and the mortality percent. The larval mortality percent increased from $22.6 \%$ at the concentration of $1.0 \mathrm{ppm}$ to $76.0 \%$ at the concentration of $10 \mathrm{ppm}$. The larval mortality percent among the control group was $13.3 \%$. The $\mathrm{LC}_{50}$ as calculated from the different mortality percentages recorded $5.09 \mathrm{ppm}$.

Table 2: Effect of different concentrations of $\mathrm{CuSO}_{4}$ on larval mortality of C. pipiens.

\begin{tabular}{|c|c|c|c|c|}
\hline Conc. ppm & No. of Larvae tested & No. of larvae died & $\begin{array}{c}\text { mortality } \\
\text { Percent }\end{array}$ & $\begin{array}{c}\text { LC } \\
\text { (ppm) }\end{array}$ \\
\hline 1 & 75 & 17 & 22.6 & \multirow{2}{*}{5.09} \\
\hline 2 & 75 & 24 & 32.00 & \multirow{2}{*}{5} \\
\hline 4 & 75 & 38 & 70.6 & \\
\hline 8 & 75 & 53 & 76.00 & \\
\hline 10 & 75 & 57 & 13.3 & \\
\hline
\end{tabular}

\section{C- Lead:}

Data given in table (3) Showed the larval mortality percentages among the larvae treated with different concentrations of lead nitrate $\left(\mathrm{Pb}\left(\mathrm{NO}_{3}\right)_{2}\right)$ as well as the untreated ones (control). The results indicated that the larval mortality percent increased as the concentration of $\mathrm{Pb}\left(\mathrm{NO}_{3}\right)_{2}$ increased. The larval mortality percent increased from $4.0 \%$ at the concentration of $8.0 \mathrm{ppm}$ to $93.3 \%$ at the concentration of 75 ppm. The larval mortality percent was $4.0 \%$ among the control group. The calculated $\mathrm{LC}_{50}$ from the different mortality percentages recorded $45.36 \mathrm{ppm}$. 
Table 3: Effect of different concentrations of $\mathrm{Pb}\left(\mathrm{NO}_{3}\right)_{2}$ on larval mortality of $C$. pipiens.

\begin{tabular}{|c|c|c|c|c|}
\hline $\begin{array}{c}\text { Conc. } \\
\text { ppm }\end{array}$ & No. of Larvae tested & No. of larvae died & $\begin{array}{c}\text { mortality } \\
\text { Percent }\end{array}$ & $\begin{array}{c}\mathbf{L C}_{50} \\
(\mathrm{ppm})\end{array}$ \\
\hline 8 & 75 & 3 & 4.00 & \multirow{6}{*}{45.36} \\
\hline 16 & 75 & 9 & 12.00 & \\
\hline 32 & 75 & 12 & 29.3 & \\
\hline 50 & 75 & 22 & 48.00 & \\
\hline 75 & 75 & 36 & 93.3 & \\
\hline Control & 75 & 3 & 4.00 & \\
\hline
\end{tabular}

\section{D- Mercury:}

The results presented in table (4) indicated that the mortality percent among the larvae treated by different concentrations of mercuric nitrate $(\mathrm{Hg}$ $\left.\left(\mathrm{NO}_{3}\right)_{2}\right)$ increased as the concentration increased.

The larval mortality percent increased from $28 \%$ at the concentration of $0.1 \mathrm{ppm}$ to $93.3 \%$ at the concentration of $1.0 \mathrm{ppm}$. The larval mortality percent was $14.6 \%$ among the untreated control group. The calculated $\mathrm{LC}_{50}$ recorded 0.44 ppm.

Table 4: Effect of different concentrations of $\mathrm{Hg}\left(\mathrm{NO}_{3}\right)_{2}$ on larval mortality of C. pipiens.

\begin{tabular}{|c|c|c|c|c|}
\hline $\begin{array}{c}\text { Conc. } \\
\text { ppm }\end{array}$ & $\begin{array}{c}\text { No. of larvae } \\
\text { tested }\end{array}$ & $\begin{array}{c}\text { No. of larvae } \\
\text { died }\end{array}$ & $\begin{array}{c}\text { Mortality } \\
\text { percent }\end{array}$ & \multirow{2}{*}{$\begin{array}{c}\text { LC }_{\mathbf{5 0}} \\
\text { (ppm) }\end{array}$} \\
\hline 0.1 & 75 & 21 & 28 & \multirow{2}{*}{} \\
\cline { 1 - 4 } & 75 & 28 & 37.3 & \multirow{2}{*}{0.44} \\
\hline 0.2 & 75 & 37 & 49.3 & \multirow{2}{*}{} \\
\hline 0.5 & 75 & 55 & 73.3 & \\
\hline 1.0 & 75 & 70 & 93.3 & \\
\hline control & 75 & 11 & 14.6 & \\
\hline
\end{tabular}

From the aforementioned results (Table 5) may be arranged in descending it is obvious that the toxicity values of order as follows: $\mathrm{CdCl}_{2}>\mathrm{Hg}\left(\mathrm{NO}_{3}\right)_{2}>$ the tested heavy metals based on $\mathrm{LC}_{50} \quad \mathrm{CuSO}_{4}>\mathrm{Pb}\left(\mathrm{NO}_{3}\right)_{2}$.

Table 5: Toxicity of different heavy metal salts against larvae of C. pipiens.

\begin{tabular}{|l|c|c|c|}
\hline \multicolumn{1}{|c|}{ Heavy metal salts } & $\mathrm{LC}_{50}(\mathrm{ppm})$ & Slope (b) & Correlation Coefficient (r) \\
\hline Cadmium chloride & 0.11 & 268.46 & 0.9796 \\
\hline Copper sulphate & 5.1 & 6.2996 & 0.9830 \\
\hline Lead nitrate & $45 . £$ & 1.1997 & 0.9815 \\
\hline Mercuric nitrate & 0.44 & 75.194 & 0.9903 \\
\hline
\end{tabular}




\section{1- 2- Fecundity:}

The number of eggs laid per female (fecundity) for $C$. pipiens females resulted from treated larvae with the $\mathrm{LC}_{50}$ of $\mathrm{CdCl}_{2}, \mathrm{CuSO}_{4}, \mathrm{~Pb}\left(\mathrm{NO}_{3}\right)_{2}$ and $\mathrm{Hg}$ $\left(\mathrm{NO}_{3}\right)_{2}$-salts and others (untreated) is given in table (6). As shown from the results there was a significant decrease
( $p>0.05$ ) of eggs laid by females resulted from larvae treated with the $\mathrm{LC}_{50}$ of $\mathrm{CdCl}_{2}, \mathrm{CuSO}_{4}, \mathrm{~Pb} \quad\left(\mathrm{NO}_{3}\right)_{2}$ and $\mathrm{Hg}$ $\left(\mathrm{NO}_{3}\right)_{2}$, where the fecundity was $81.7 \pm 5.03, \quad 90.3 \pm 2.52, \quad 92.7 \pm 3.5$ and $78.6 \pm 1.52 \quad$ eggs/ + ; respectively, compared to $186 \pm 4 \mathrm{eggs} / \mathrm{Q}$ for the untreated females (control).

Table 6: Fecundity and egg hatchability of $C$. pipiens as affected by treatment of $2^{\text {nd }}$ larval instars with the $\mathrm{LC}_{50}$ of different heavy metal salts.

\begin{tabular}{|l|c|c|c|c|c|c|}
\hline & \multirow{2}{*}{ Heavy metal salts Conc.(ppm) } & \multirow{2}{*}{$\begin{array}{c}\text { LC } \\
(\mathrm{ppm})\end{array}$} & $\begin{array}{c}\text { No. of } \\
\text { females } \\
\text { tested }\end{array}$ & \multicolumn{2}{|c|}{$\begin{array}{c}\text { No. of egg } \\
\text { laid/female }\end{array}$} & \multicolumn{3}{|c|}{$\begin{array}{c}\text { No. of egg } \\
\text { hatched }\end{array}$} \\
\cline { 6 - 8 } & & Total & Mean \pm SD & Total & $\%$ \\
\hline Cadmium Chloride & 0.11 & 25 & 2041 & $81.7 \pm 5.03 * * *$ & 755 & 37.0 \\
\hline Copper Sulphate & 5.1 & 25 & 2258 & $90.3 \pm 2.52^{* * *}$ & 1648 & 73.0 \\
\hline Lead nitrate & 45.4 & 25 & 2316 & $92.7 \pm 3.5 * * *$ & 1853 & 80.0 \\
\hline Mercuric nitrate & 0.44 & 25 & 1966 & $78.6 \pm 1.52 * * *$ & 767 & 39.0 \\
\hline Control & -- & 25 & 4650 & $186.4 \pm 4$ & 4510 & 97.0 \\
\hline$* * *=$ Very highly significant & & & & & &
\end{tabular}

\section{1-3- Egg hatchability:}

The hatchability percent of eggs laid by $C$. pipiens females resulted from treated larvae with the $\mathrm{LC}_{50}$ of $\mathrm{CdCl}_{2}$, $\mathrm{CuSO}_{4}, \mathrm{~Pb}\left(\mathrm{NO}_{3}\right)_{2}$ and $\mathrm{Hg}\left(\mathrm{NO}_{3}\right)_{2}$, and the other resulted from untreated larvae is also given in table (6). The results indicated that heavy metal salts used decreased significantly the hatchability percent of eggs laid by females resulted from treated larvae as compared with the control. The hatchability percent recorded was $37,73,80$ and $39 \%$ for eggs laid by females treated with the $\mathrm{LC}_{50}$ of $\mathrm{CdCl}_{2}, \mathrm{CuSO}_{4}, \mathrm{~Pb}\left(\mathrm{NO}_{3}\right)_{2}$ and $\mathrm{Hg}\left(\mathrm{NO}_{3}\right)_{2}$; respectively, compared to $97 \%$ for eggs laid by females resulted from untreated larvae.

2- Effect of heavy metals on some biochemical parameters in $C$. pipiens: 2-1- Total carbohydrates content:

Data given in table (7) show the changes in the total carbohydrate content in the homogenate of the whole body of C. pipiens adults resulted from larvae treated with the $\mathrm{LC}_{50}$ of $\mathrm{CdCl}_{2}, \mathrm{CuSO}_{4}$, $\mathrm{Pb}\left(\mathrm{NO}_{3}\right)_{2}$ and $\mathrm{Hg}\left(\mathrm{NO}_{3}\right)_{2}$.
The results indicated a very highly significant $(\mathrm{p}>0.001)$ and a highly significant $(p>0.01)$ decrease in total carbohydrate content in the whole body of males and females resulted from larvae treated with the $\mathrm{LC}_{50}$ of $\mathrm{CdCl}_{2}$; respectively. The total carbohydrate recorded 0.09 and $0.08 \mathrm{mg} / \mathrm{ml}$ compared to 0.13 and $0.13 \mathrm{mg} / \mathrm{ml}$ for untreated males and females; respectively. Also a very highly significant $(p>0.001)$ decrease in the total carbohydrate content in both males and females resulted from larvae treated with the $\mathrm{LC}_{50}$ of $\mathrm{Hg}\left(\mathrm{NO}_{3}\right)_{2}$ was found, where it recorded 0.07 and $0.08 \mathrm{mg} / \mathrm{ml}$ compared to 0.13 and 0.13 $\mathrm{mg} / \mathrm{ml}$ for untreated males and females; respectively.

On the other hand, the change in total carbohydrate content in males and females resulted from larvae treated with the $\mathrm{LC}_{50}$ of $\mathrm{CuSO}_{4}$ was non significant, while in males and females resulted from larvae treated with the $\mathrm{LC}_{50}$ of $\mathrm{Pb}\left(\mathrm{NO}_{3}\right)_{2}$ was significant ( $p>0.05)$. It recorded 0.12 and $0.12 \mathrm{mg} / \mathrm{ml}$ in males and females resulted from larvae treated with the $\mathrm{LC}_{50}$ 
of $\mathrm{CuSO}_{4}$ and 0.11 and $0.11 \mathrm{mg} / \mathrm{ml}$ in males and females resulted from larvae treated with the $\mathrm{LC}_{50}$ of $\mathrm{Pb}\left(\mathrm{NO}_{3}\right)_{2}$; respectively. By comparing the percentages of reduction in the total carbohydrate content of males and females resulted from larvae treated with $\mathrm{CdCl}_{2}$ and $\mathrm{Hg}\left(\mathrm{NO}_{3}\right)_{2}$ it seemed that mercury caused the highest reduction percent $46.15 \%$ in the total carbohydrate content of males, while cadmium caused reduction percentages of 30.76 and 38.46 in total carbohydrate of males and females; respectively.

Table 7: Changes in the total Carbohydrate Contents of $C$. pipiens resulted from larvae treated with the $\mathrm{LC}_{50}$ of different heavy metal salts.

\begin{tabular}{|l|c|c|c|}
\hline \multicolumn{1}{|c|}{ Treatments } & $\begin{array}{c}\mathrm{LC}_{50} \\
\text { ppm }\end{array}$ & $\begin{array}{c}\text { Carbohydrates }(\mathrm{mg} / \mathrm{ml}) \\
\text { Mean } \pm \mathrm{SD}\end{array}$ & $\begin{array}{c}\text { Change } \\
\text { percent }\end{array}$ \\
\hline Control (male) & -- & $0.13 \pm 0.01$ & -- \\
\hline Control (female) & -- & $0.13 \pm 0.01$ & -- \\
\hline $\mathrm{CdCl}_{2}$ (male) & 0.11 & $0.09^{* *} \pm 0.002$ & -30.76 \\
\hline $\mathrm{CdCl}_{2}$ (female) & 0.11 & $0.08^{* *} \pm 0.009$ & -38.46 \\
\hline $\mathrm{CuSO}$ (male) & 5.1 & $0.12 \pm 0.001$ & -7.69 \\
\hline $\mathrm{CuSO}$ (female) & 5.1 & $0.12 \pm 0.001$ & -7.69 \\
\hline $\mathrm{Pb}\left(\mathrm{NO}_{3}\right)_{2}$ (male) & 45.4 & $0.11^{*} \pm 0.002$ & -15.38 \\
\hline $\mathrm{Pb}\left(\mathrm{NO}_{3}\right)_{2}$ (female) & 45.4 & $0.11_{ \pm} \pm 0.001$ & -15.38 \\
\hline $\mathrm{Hg}\left(\mathrm{NO}_{3}\right)_{2}$ (male) & 0.44 & $0.07^{* * *} \pm 0.008$ & -46.15 \\
\hline $\mathrm{Hg}\left(\mathrm{NO}_{3}\right)_{2}$ (female) & 0.44 & $0.08^{* *} \pm 0.005$ & -38.46 \\
\hline
\end{tabular}

\section{2-2-Total lipids content:}

As shown from the results given in table (8) a very highly significant $(\mathrm{p}>0.001)$ and highly significant $(\mathrm{p}>$ 0.01 ) increase in total lipids content in males resulted from larvae treated with $\mathrm{LC}_{50}$ of $\mathrm{CdCl}_{2}, \mathrm{CuSO}_{4}$ and $\mathrm{Pb}\left(\mathrm{NO}_{3}\right)_{2}$ was occurred, where it recorded
$0.88+0.0013,0.16 \pm 0.01$ and $0.14 \pm 0.004$ $\mathrm{mg} / \mathrm{ml}$; respectively, compared to $0.09 \pm 0.015 \mathrm{mg} / \mathrm{ml}$ for untreated control males. The percentage of increase in total lipids was $87.8 \%, 77.78 \%$ and $55.56 \%$ for $\mathrm{CdCl}_{2}, \mathrm{CuSO}_{4}$ and $\mathrm{Pb}\left(\mathrm{NO}_{3}\right)_{2}$-treated males; respectively.

Table 8: Changes in the total Lipid Contents of $C$. pipiens resulted from larvae treated with the $\mathrm{LC}_{50}$ of different heavy metal salts.

\begin{tabular}{|c|c|c|c|}
\hline Treatments & $\begin{array}{l}\mathrm{LC}_{50} \\
\mathbf{p p m}\end{array}$ & $\begin{array}{c}\text { Lipids }(\mathrm{mg} / \mathrm{ml}) \\
\text { Mean } \pm \text { SD }\end{array}$ & $\begin{array}{l}\text { Change } \\
\text { percent }\end{array}$ \\
\hline Control (male) & -- & $0.09 \pm 0.015$ & -- \\
\hline Control (female) & -- & $0.96 \pm 0.005$ & -- \\
\hline $\mathrm{CdCl}_{2}$ (male) & 0.11 & $0.88 * * * \pm 0.0013$ & +87.8 \\
\hline $\mathrm{CdCl}_{2}$ (female) & 0.11 & $0.09 * * * \pm 0.003$ & -90.62 \\
\hline $\mathrm{CuSO}_{4}$ (male) & 5.1 & $0.16 * * \pm 0.01$ & +77.78 \\
\hline $\mathrm{CuSO}_{4}$ (female) & 5.1 & $0.14 * * * \pm 0.012$ & -85.42 \\
\hline $\mathrm{Pb}\left(\mathrm{NO}_{3}\right)_{2}$ (male) & 45.4 & $0.14 * * \pm 0.004$ & +55.56 \\
\hline $\mathrm{Pb}\left(\mathrm{NO}_{3}\right)_{2}$ (female) & 45.4 & $0.99 \pm 0.05$ & +3.13 \\
\hline $\mathrm{Hg}\left(\mathrm{NO}_{3}\right)_{2}$ (male) & 0.44 & $0.09 \pm 0.0002$ & 0 \\
\hline $\mathrm{Hg}\left(\mathrm{NO}_{3}\right)_{2}$ (female) & 0.44 & $0.81 * \pm 0.09$ & -15.62 \\
\hline
\end{tabular}

On the other hand, $\mathrm{CdCl}_{2}$ and $\mathrm{CuSO}_{4}$ caused a very highly significant ( $>0.001)$ decrease in the total lipids content of females, where it recorded
$0.09+0.003$ and $0.14 \pm 0.012 \mathrm{mg} / \mathrm{ml}$; respectively, compared to $0.96 \pm 0.005$ $\mathrm{mg} / \mathrm{ml}$ for untreated control females. The percentages of reduction were $90.62 \%$ 
and $85.42 \%$ as induced by cadmium or by copper; respectively. Also, there was a significant decrease in the total lipids content of females resulted from larvae treated with the $\mathrm{LC}_{50}$ of $\mathrm{Hg}\left(\mathrm{NO}_{3}\right)_{2}$, where it recorded $0.81+0.09$ with percentage of $15.62 \%$. However, the other changes in the total lipids as induced by other heavy metals (Table 8 ) were insignificant $(\mathrm{p}>0.05)$.

\section{DISCUSSION}

1- Effect of heavy metals on some biological parameters in Culex pipiens.

Metal pollution often reduces the fitness of organisms to such extent that species diversity in polluted environments is strongly reduced (Brown, 1977; Clements et al., 1988 and Gunn, 1995). Aquatic insects, which are often the most abundant and diverse group of benthic animals in fresh water ecosystems accumulate heavy metals and have long been exploited as indicator species of environmental pollution and for bioassays of pollutant (Hare, 1992). Moreover, aquatic insects are sensitive bioreporters of heavy metals contamination because exposure occurs during critical stage of insect development such as embryogenesis, larval development and pupation.

The biological impact of heavy metals on aquatic insects has been extensively studied in nature and in the laboratory (e.g. Clements et al., 1988; Cain et al., 1992; Timmermans et al., 1992 and Clements \& Kiffney, 1994).In addition to mortality, exposure of aquatic insects to heavy metals can result in changes in fecundity and fertility. However, some mosquitoes can survive in polluted waste water (Kitvatanachai et al., 2005). The toxicity of some heavy metals against these mosquitoes is not yet known.

In this study, the results obtained revealed that the heavy metals namely; $\mathrm{Cd}, \mathrm{Cu}, \mathrm{Pb}$ and $\mathrm{Hg}$ were found to exert biological effects on the larvae of $C$. pipiens. The survival potential of the $3^{\text {rd }}$ instar larvae was highly affected by the contamination with the heavy metals tested. A concentration dependent mortality percent was obtained i.e. the larval mortality percent increased as the concentrations of heavy metals increased. However, the present data revealed that the toxicity of heavy metals tested against the larval stage varied from one metal to another. On the basis of $\mathrm{LC}_{50}$, $\mathrm{Cd}$ was the most toxic metal against the larval stage followed by $\mathrm{Hg}, \mathrm{Cu}$ and $\mathrm{Pb}$. These results are in agreement with those obtained by Migula (1989), where he reported high toxicity of cadmium followed by lead against Acheta domesticus.

Heavy metal effects on larval mortality were not unexpected and similar results have been observed in other dipterans (Hare, 1992). In general, deleterious effects were directly proportional to metal concentration. The present results are in a harmony with that of Hafez et al. (1999) who found that survivorship of $C$. pipiens larvae significantly decreased as the concentration of cadmium increased. Also, Salama (2002) proved that the larval mortality percent of C. pipiens increased as the concentration of contaminants namely; $\mathrm{Cd}, \mathrm{Hg}$ and $\mathrm{Pb}$ increased.

The present data have shown also that the $\mathrm{LC}_{50}$ was $0.11,5.09,45.36$ and $0.44 \mathrm{ppm}$ for $\mathrm{Cd}, \mathrm{Cu}, \mathrm{Pb}$ and $\mathrm{Hg}$; respectively, against $C$. pipiens larvae. Meanwhile, Jiang et al. (1988) reported that, the $\mathrm{LC}_{50}$ was $10.5 \mathrm{ppm}$ on the larvae of $C$. pipiens pallens. The $\mathrm{LC}_{50}$ of the heavy metals studied may be comparable with that obtained by Rayms-Keller et al. (1998) against Aedes aegypti larvae and Salama (2002) against C. pipiens larvae.

The toxicity action of heavy metals has been reported also against several species of insects. Pascoe et al. (1989) found that, relatively high larval mortality occurred during the first instar 
larvae of Chironomus riparius (Meigen) treated with cadmium and this action increased as the concentration of cadmium increased. The present data were in harmony with these observations. Contrary, Timmermans et al., (1992) showed that long term exposure experiments with low cadmium concentrations resulted in high mortality in first instar stages of $C$. riparius (Meigen).

Concerning the effect of heavy metals on reproduction, reports on the acute and chronic toxic effects of heavy metals on insect reproduction are frequent in literature. Several studies have demonstrated pleiotrophic chronic effects of $\mathrm{Cd}$ on insect physiology, affecting processes such as growth, development, reproduction and/or hatchability (Van-Straalen et al., 1989; Mathova, 1990; Schmidt et al., 1992; Gintenreiter et al., 1993; Rayms-Keller et al., 1998 and Sildanchandra \& Crane, 2000). However, the interruption of insect reproduction is an important and potent effect for heavy metals.

The present study has shown that the delayed toxicity of heavy metals on the adult females resulted from larvae treated with the $\mathrm{LC}_{50}$ of the heavy metals tested decreased significantly the number of eggs. The fecundity was $81.7 \pm 5.03$, $90.3 \pm 2.52, \quad 92.7 \pm 3.5$ and $78.6 \pm 1.52$ eggs/ $q$ for females resulted from larvae treated with the $\mathrm{LC}_{50}$ of $\mathrm{CdCl}_{2}, \mathrm{CuSO}_{4}$, $\mathrm{Pb}\left(\mathrm{NO}_{3}\right)_{2}$ and $\mathrm{Hg}\left(\mathrm{NO}_{3}\right)_{2}$; respectively, compared to $186 \pm 4$ eggs/ $q$ for untreated females (control). These results may be comparable with those obtained by Salama (2002) using different concentrations against the $3^{\text {rd }}$ larval instar of C. pipiens. Also, the reduction in fecundity of females resulted from larvae treated with the $\mathrm{LC}_{50}$ as indicated in the present results was in agreement with that of William et al. (1987) who demonstrated that female, $C$. riparius laid fewer eggs in high cadmium concentrations (300 and $100 \mathrm{mg} / \mathrm{l})$ than in lower concentrations or clean water. Moreover, the present study has shown that lead significantly reduced the fecundity of $C$. pipiens females which was in accordance with observations of Kitvatanachai et al., (2005) on Culex quinquefasciatus.

The observed inhibition of hatching of eggs laid by females resulted from larvae treated with the $\mathrm{LC}_{50}$ of the heavy metals tested as indicated in the present study was in agreement with Rayms-Keller et al., (1998) using Cd, $\mathrm{Cu}, \mathrm{Pb}$ and $\mathrm{Hg}$ against $A$. aegypti, Salama (2002) using $\mathrm{Cd}, \mathrm{Cu}, \mathrm{Pb}, \mathrm{Hg}$ and $\mathrm{Zn}$ against $C$. pipiens and Kitvatanachai et al., (2005) using $\mathrm{Pb}$ against $C$. quinquefasciatus. However, Romi et al. (2000) found that there were no effects on egg hatchability of Aedes albopictus treated with $\mathrm{CuSO}_{4}$.

\section{2- Effect of heavy metals on some biochemical parameters in $C$. pipiens.}

With regard to environmental contamination, research on heavy metals effects on mosquito biochemistry has started only recently. Only scattered information on effects of heavy metal stress on metabolism is available. Conclusion on how heavy metals interfere with general metabolic pathways can probably be drawn from the determination of total proteins, carbohydrates and lipids in the haemolymph or the target organ or even the whole body.

The present study has shown a significant decrease in total carbohydrates content in the whole body of males and females, C. pipiens resulted from larvae treated with the $\mathrm{LC}_{50} \mathrm{CdCl}_{2}$ or the $\mathrm{LC}_{50}$ of $\mathrm{Hg}\left(\mathrm{NO}_{3}\right)_{2}$. Meanwhile, the change in total carbohydrates content in males and females, C. pipiens resulted from larvae treated with the $\mathrm{LC}_{50} \mathrm{CuSO}_{4}$ or $\mathrm{Pb} \quad\left(\mathrm{NO}_{3}\right)_{2}$ was insignificant. The present study has shown also a significant decrease in total lipids content of females by the $\mathrm{LC}_{50}$ of $\mathrm{CuSO}_{4}$ and the $\mathrm{LC}_{50}$ of $\mathrm{Hg}\left(\mathrm{NO}_{3}\right)_{2}$, while a significant 
increase was caused in males by the $\mathrm{LC}_{50}$ of $\mathrm{CuSO}_{4}$ and $\mathrm{LC}_{50}$ of $\mathrm{Pb}\left(\mathrm{NO}_{3}\right)_{2}$.

The effect of heavy metals tested on total carbohydrates and lipids in adults, C. pipiens is in accordance with observations of other authors. Cadmium toxicity on metabolic processes has already been demonstrated for $A$. domesticus, where Cd-contaminated food caused a strong inhibition of the respiratory metabolism (Migula, 1989), reduced the assimilation efficiency and increased the energetic maintenance costs during development (Migula et al., 1989). Radhakrishnaiah and Busappa (1986) demonstrated shifts in the carbohydrate metabolism in the fresh water field crab, Oziotelphusa senex senex due to exposure to sublethal concentration of cadmium. Bischof (1995) reported a drastical decrease of glycogen in the body tissue of Lymantria dispar larvae after cadmium and zinc contamination. In addition, lipid concentration declined in the haemolymph and total body tissue due to the two heavy metals. Also, the present results agree with Ortel (1996), where he demonstrated that whole body lipid concentration of day-3 ( $4^{\text {th }}$ instar) larvae of $L$. dispar was significantly reduced due to cadmium concentration.

There are also some reports dealing with effects of heavy metals on total carbohydrates and lipids in insects which support the present results. For example, Islam and Roy (1983) reported a significant decrease in levels of lipids and carbohydrates in haemolymph, fat body and ovaries of bug, Chrysocharis stolli after injection with $5 \mu \mathrm{g} \mathrm{Cd}$ per individual. Also, a significant decrease in total lipid content in Cd-contaminated larvae and pupae of the greater wax moth, Galleria mellonella was observed by Byung-Silk et al. (2001).

Generally, the present results have shown that the two heavy metals, cadmium and mercury were found to be the most effective ones in inducing the decline of the main metabolites which agree the previous finding of the aforementioned authors. Meanwhile, copper and lead were insignificant in this respect. These results are in harmony with that of Cass and Hill (1980), whom found that copper and zinc are metals of great importance in biological processes and metabolism, where they are enzymatic factors. Also copper is a constituent of several insect enzymes including phenol oxidase and tyrosinae (Nilsson, 1970; Hackman, 1974; McFarlane, 1974 and Bagatto \& Shorthouse, 1996) and this may explain that copper is an essential ion in insect metabolism.

\section{REFERENCES}

Armitage, P. (1974): Paired student ' $t$ ' test. In 'Statistical methods in medical research' Black well Scientific Pub. Oxford, London, 116-120.

Bagatto, G. and Shorthouse, J.D. (I996): Accumulation of $\mathrm{Cu}$ and $\mathrm{Ni}$ in successive stages of Lymantria dispar L. (Lymantriidae, Lepidoptera) near Ore smelters at Sudbury, Ontario. Canada. Environ. Pollut., 92(1): 7-12.

Biney, C., Amazu, A.T., Calamari, D., Kaba, N., Mbome, I.L., Naeve, H., Ochumba, P.B.O., Osibanjo, O., Radegonde, V., Saad, M., (1994): Review of heavy metals in the African aquatic Environment. Ecotoxicol. Environ. Saf. 28, 134-159.

Bischof, C. (1995): Effects of heavy metal stress on carbohydrate and lipid concentrations in the haemolymph and total body tissue of parasitized Lymantria dispar L. larvae (Lepidoptera). Comp. Biochem. Physiol., 112C. (1): 8792.

Briggs, J.N. (1960): Reduction of adult house fly emergence by the effective Bacillus sp. on the 
development of immature forms. J. Insect Pathol., 2: 418-432.

Brown, B.E. (1977): Effects of mine drainage on the river Hayle, Cornwall. Factors affecting concentrations of copper, zinc and iron in water, sediments and dominant invertebrate fauna. Hydrobiologia, 52: 221-233.

Byung-Sik, S.; Choi, R.N. and Lee, C.U. (2001): Effects of cadmium on total lipid content and fatty acids of the greater wax moth, Galleria mellonella. Korean J. Ecol., 24(6): 349-352.

Cain, D.J.; Luoma, S.N.; Carter, J.L. and Fend, S.V. (1992): Aquatic insects as bioindicators of trace element contamination in cobble bottom rivers and streams. Can. J. Fish. Aquat. Sci., 49: 2141-2154.

Cass, A.E.G. and Hill, H.A.O. (1980): Copper proteins and copper enzymes. Ciba. Fdn. Symp., 79: 7191.

Chinery, W.A., (1984): Effects of ecological changes on the malaria vectors Anopheles funestus and Anopheles gambiae complex of mosquitoes in Accra, Ghana. J. Trop. Med. Hyg. 87, 75-81.

Clements, W.H. and Kiffney, P.M. (1994): Integrated laboratory and field approach for assessing impacts of heavy-metals at the Arkansas River, Colorado. Environ. Toxicol. Chem., 13: 397-404.

Clements, W.H.; Cherry, D.S. and Cairns, J. (1988): Impact of heavy metals on insect communities in streams: A comparison of observational and experimental results. Can. J. Fish. Aquat. Sci., 45: 2017-2025.

Coene, J., (1993): Malaria in urban and rural Kinshasa: the entomological input. Med. Vet. Entomol. 7, 127-137.

Coluzzi, M., (1993): Advances in the study of Afrotropical malaria vectors. Parasitologia 35, 23-29.
Dallinger, R. (1994): Invertebrate organism as biological indicator of heavy metal pollution. Appl. Biochem. Biotechnol., 48: 27-31.

Darwish, M. and Hoogstraal, H. (1981): Arboviruses infesting human and lower animals in Egypt. A review of thirty years of research. J. Egypt. Pub. Hlth. Assoc., 56: 1-112.

Finney, D.J. (1971): Probit analysis third edition. Cambridge Univ. Press, $333 \mathrm{p}$.

Frings, C.S.; Fendly, T.W.; Dunn, R.T. and Queen, C.A. (1972): in practicle clinical chemistry by celsom. T. and Philip, G. A. Ed by little, Brown and company U.S.A.

Gad, A.M.; Hammad, R.E. and Farid, H.A. (1996): Uptake and development of Wuchereria bancrofti in Culex pipiens L. and Aedes caspius pallas. J. Egypt. Soc. Parasitol., 26(2): 305-314.

Gintenreiter, S.; Ortel, J. and Nopp, H.J. (1993): Effects of different dietary levels of cadmium, lead, copper and zinc on the vitality of the forest pest insect Lymantria dispar L. (Lymantriidae, Lepid). Arch. Environ. Contam. Toxicol., 25: 62-66.

Gunn, J.M. (1995): Restoration and recovery of an industrial region, ed. J. M. Gunn. Springer Verlag, New York. NY, U.S.A.

Hackman, R.H. (1974): Chemistry of the insect cuticle. The physiology of insecta, (ed M. Rodstein), 6: 216270. Academic press, London.

Hafez, G.A.; Aly, S.A. and El-Ebiarie, A.S. (1999): Effect of some Heavy metals alone and combined with bacteria on the survivorship of Culex pipiens larvae. J. Egypt. Ger. Soc. Zool., 30: 61-75.

Hare, L. (1992): Aquatic insects and trace metals: bioavailability, bioaccumulation and toxicity. Crit. Rev. Toxicol., 22: 327 -369.

Hassan, M.I.; Zayed, A.B. and Ahmed, M.S. (1996): The influence of 
symbiotic bacteria on digestion and yolk protein synthesis in Culex pipiens L. (Diptera: Culicidae). J. Egypt. Ger. Soc. Zool., 21(E), Entomol., 269-284.

Islam, A. and Roy, S. (1983): Effects of $\mathrm{CdCl}_{2}$ on the quantitative variations of carbohydrate, protein, amino acid and cholesterol in Chrysochoris stolli Wolf (Insecta: Hemiptera). Curr. Sci., 52: 215217.

Jiang, J.L.; Wang, S.W.; Chen, Q.Y.; Xu, W. and Lin, G.F. (1988): Study on toxic effect and accumulation of cadmium chloride in mosquito larva Culex pipiens pallens. Contributions-From-ShanghaiInstitute of Entomol., 8: 147-152.

Kasap, M. and Demirhan, O. (1992): The effect of various larval foods on the rate of adult emergence and fecundity of mosquitoes. Turkiye parazitologi Dergisi, 161: 87-97.

Khalil, M.; Malawani, A. and Hilmi, I.S. (1930): the transmission of Bancroftian filariasis in Egypt. J. Egypt. Med. Assoc., 15: 315-332.

Kitvatanachai, S.; Apiwathnasorn, C., Leemingsawat, S.; Wongwit, W. and Tornee, S. (2005): determination of lead toxicity in Culex quinquefasciatus mosquitoes in the laboratory Southeast Asian. J .Trop. Med. Pub. Hlth., 36(4): 862874.

Lentner, C.; Lentner, C. and Wink, A. (1982): Students t-distribution tables. In Geigy Scientific Tables Vol. 2. International Medical and Pharmaceutical informaiton, Ciba Geigy Limited, Basal, Switzerland.

Mathova, A. (1990): Biological effects and biochemical alteration after long-term exposure of Galleria mellonella (Lepidoplera, Pyralidael) larvae to cadmium containing diet. Acta-Entomologica Bohemoslovaca, 87(4): 241-248.
McFarlane, J.F. (1974): The functions of copper in the house cricket and the relation of copper to vitamin $\mathrm{H}$. Canad. Entomol., 106: 441-446.

Meagan, J.M.; Khalil, G.M.; Hoogstraal, H. and Adham, F.K. (1980): Experimental transmission and field isolation studies implicating Culex pipiens as a vector of Rift Valley virus in Egypt. Am. J. Trop. Hyg., 80: 1405-1410.

Mireji, P.O.; Keating,J.; Hassanali, A.; Mbogo, C.M.; Nyambaka, H.; Kahindi, S. and Beier, J.C. (2008): Heavy metals in mosquito larval habitats in urban Kisumu and Malindi, Kenya, and their impact. Ecotoxicology and Environ. Safety., 70 (1): 147-153.

Migula, P. (1989): Combined and separate effects of cadmium, lead and zinc on respiratory metabolism during the last larval stage of the house cricket. Acheta domesticus. Biologia-Bratislava, 44(6):513-521.

Nilsson, R. (1970): Aspects of the toxicity of cadmium and its compounds. Ecol. Res. Committee Bull. (7), Swedish Natural Science Council, Stockholm.

Ortel, J. (1996): Metal-supplemented diets alter carbohydrate levels in tissue and hemolymph of gypsy moth larvae (Lymantria dispar, Lymantriidae, Lepidoptera). Environ. Toxicol. Chem., 15: 11711176.

Pascoe, D.; Williams, K.A. and Green, D.W.J. (1989): Chronic toxicity of cadmium to chironomus riparius Meigen- effects upon larval development and adult emergence, Hydrobiologia, 175: 109-115.

Pelah, D.; Abramovich, Z.; Markus, A. and Wiesman, Z. (2002): The use of commercial saponin from Quillaje saponaria barks as a natural larvicidal agent against Aedes aegypti and Culex pipiens. J. Ethnopharmacol., 81 (3): 407- 409. 
Radhakrishnaiah, K. and Busappa, B. (1986): Effects of cadmium on the carbohydrate metabolism of the freshwater field crab Oziotelphusa senex senex (Fabricius). J. Environ. Biol., 7(1): 17-21.

Rayms-Keller, A.; Oslon, K.E.; McGaw, M.; Oray, C.; Carbon, J.O. and Beaty, B.J. (1998): Effect of heavy metals on Aedes aegypti (Diptera: Culicidae) larvae. Ecotoxicol. Environ. Safe, 39: 41-47.

Romi, R.; Diluca, M.; Raineri, W.; Pesce, M.; Rey, A.; Giovannangeli, S.; Zanasi, F. and Bella, A. (2000): Laboratory and field evaluation of metallic copper on Aedes albopictus (Diptera. Culicidae) larval development. J. Med. Entomol., 37(2): 281-285.

Salama (2002): Bioaccumulation and effects of certain heavy metal ions in Culex Pipiens L. (Diptera: Culicidae). M. Sc. Thesis, Faculty of Science, Al-Azhar University (Girls), Cairo, Egypt.

Schmidt, G.H.; Ibrahim, N.M.M. and Abdallah, M.D. (1992): Long-term effects of heavy metals in food on developmental stages of Aiolopus thalassinus (Saltatoria: Acrididae). Arch. Environ. Contam. Toxicol., 23: 375-382.

Sildanchandra, W. and Crane, M. (2000): Influence of sexual dimorphism in Chironomus riparius Meigen on toxic effects of cadmium. Environ. Toxicol. Chem., 19: 2309-2313.

Timmermans, K.R.; Peeters, W. and Tonkes, M. (1992): Cadmium, zinc, lead and copper in Chironomus riparius (Meigen) larvae (Diptera. Chironomidae): uptake and effects. Hydrobiologia, 241: 119-134.

Trape, J.F., Zoulani, A., (1987): Malaria and urbanization in central Africa: The example of Brazzaville. Part II: Results of entomological surveys and epidemiological analysis. Trans. R. Soc. Trop. Med. Hyg. 81, 10-18.

Van-Straalen, N.M.; Schobben, J.H.M. and De-Goede, R.G.M. (1989): Population consequences of cadmium toxicity in soil microarthropods. Ecotoxicol. Environ. Safe, 17: 190-204.

Williams, K.A.; Green, D.W.J.; Pascoe, D. and Gower, D.E. (1986): The acute toxicity of cadmium to different larval stages of Chironomus riparius (Diptera. Chironomidae) and its ecological significance for pollution regulation. Oecologia, 70: 362-366.

Williams, K.A.; Green, D.W.J.; Pascoe, D. and Gower, D.E. (1987): Effect of cadmium on oviposition and egg viability in Chironomus riparius (Diptera: Chironomidae). Bull. Environ. Contam. Toxicol., 38: 8690. 


\section{ARABIC SUMMARY}

التأثيرات السمية لبعض ايونات العناصر الثقيلة على بعوضة كيولكس ببينز (ثنائية الأجنحة: كيولسيدى)

طارق محمد يسرى الثيخ- محمد عبد الحي فوده- مصطقى إبراهيم حسن - عبد الحميد عبد الفتاح عبد إلفي

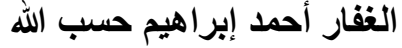

قسم علم الحيوان- كلية العلوم- جامعة الأزهر-القاهرة (بنين).

تم في هذه الدراسة معاملة الدور اليرقى الثناني لبعوضة كبولكس بيينز بتركيزات معينة من الزئن العناصر

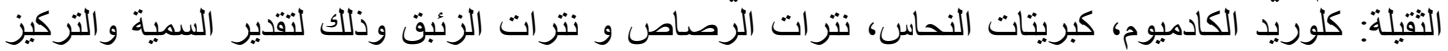

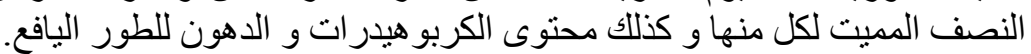

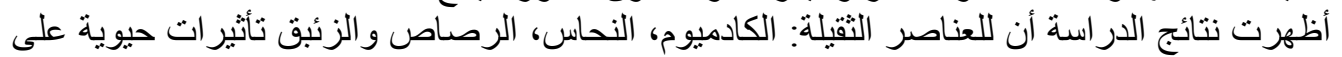

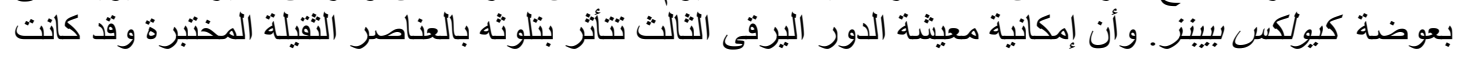

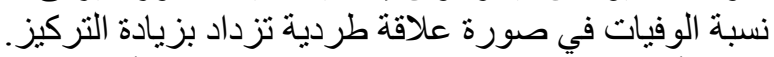

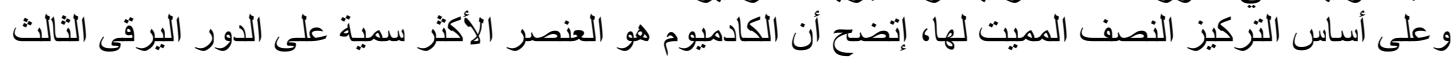
يليه الزئبق ثم النحاس ثم النزيز الرصاص.

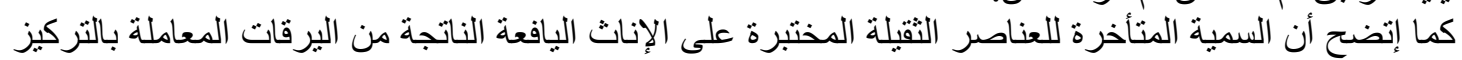

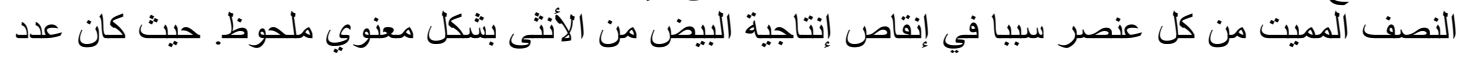

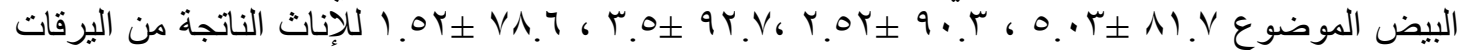

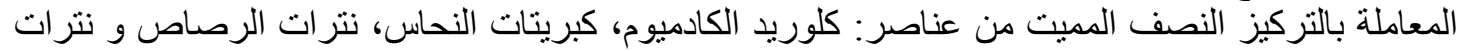

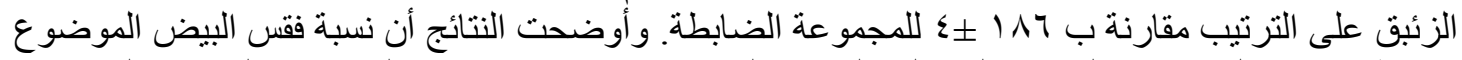

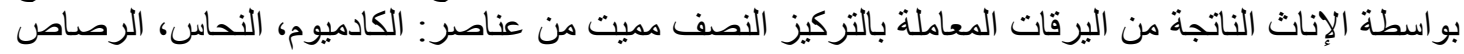

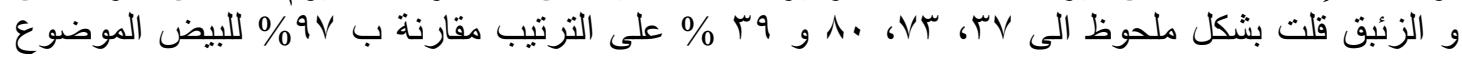

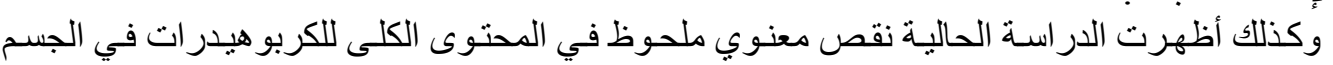

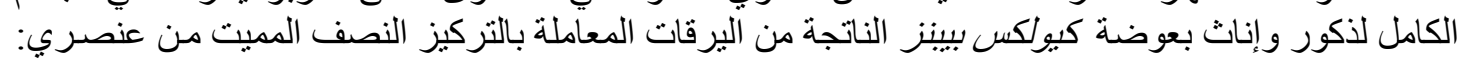

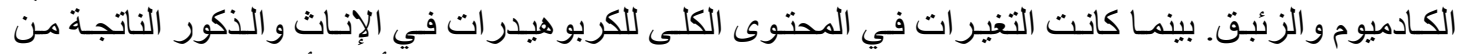

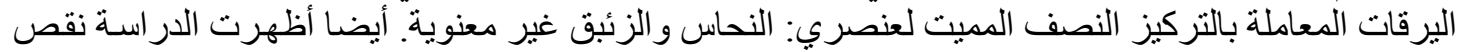

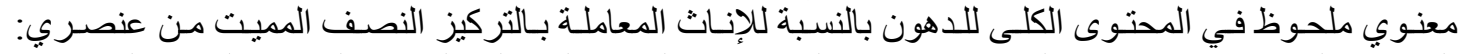

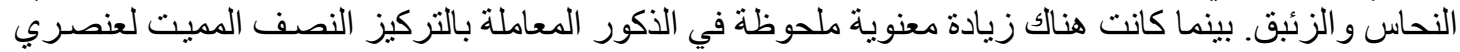

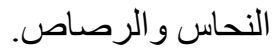

ويتضح من النتائج المتحصل عليها في هذه الدراسة أن وجود مثل هذه العناصر في النظام البيئي المائي لبعوض الكيولكس ممكن أن تساهم في الحد من تكاثر البعوض. 